\title{
Study of lipid profile levels in malnourished and healthy children: a case control study
}

\author{
Verma G.K. ${ }^{1}$, Yadav Y.S. ${ }^{2}$, Yadav R.K. ${ }^{3}$, Sharma I.K. ${ }^{4}$, Bharat K. ${ }^{5}$, Yadav K.K. ${ }^{6}$ \\ ${ }^{1}$ Dr. Ganesh Kumar Verma, Department of Paediatrics, Uttar Pradesh University of Medical Science, Saifai, UP. \\ Department of Paediatrics, Maharani Laxmi Bai Medical College, Jhansi, UP, ${ }^{2}$ Dr. Yogendra Singh Yadav, ${ }^{3}$ Dr. Rajesh \\ Kumar Yadav, ${ }^{4}$ Dr. Indra Kumar Sharma, ${ }^{5}$ Dr. Kunwar Bharat, all are Department of Paediatrics, Uttar Pradesh \\ University of Medical Science, Saifai, UP, ${ }^{6}$ Dr. Krishan Kumar Yadav, Department of Paediatrics, Ram Manohar Lohia \\ Institute of Medical Science, Lucknow, UP, India.
}

Corresponding Author: Dr Yogendra Singh Yadav, Department of Paediatrics, Uttar Pradesh University of Medical Science (UPUMS), Saifai, Etawah, Uttar Pradesh, India. Email ID: dryogendra83@gmail.com

\begin{abstract}
Background: Under nutrition causes reduced growth and endocrine adaptations in order to maintain basic life processes. Protein energy malnutrition often coexists with micronutrient deficiencies. Malnutrition results from multiple deficiencies, not necessarily limited to lack of proteins or calories, but also involving other associated or separate factors such as deficiency of trace elements, such as copper and zinc and lipid profile. Methods: A case control study was carried out in department of Pediatrics, Maharani Laxmi Bai (MLB) Medical College, Jhansi from September 2009 to August 2010. 108 cases \& 108 matched controls were recruited according to sex, weight and height after written informed consent with the approval of ethical committee. Total cholesterol and fractions (low-density lipoprotein cholesterol, high density lipoprotein cholesterol) and triglycerides concentrations were determined by automated enzymatic methods. The results were analyzed by the appropriate statistical test. Results: In present study, more than half children were suffered from marasmus as an acute malnutrition and most of children were of below 24 months of age. Total cholesterol, triglyceride and HDL levels were lower in PEM children while LDL \& VLDL levels were higher in malnourished children group. Conclusion: The prevalence of under nutrition and dyslipidaemia observed in these children is a matter of concern considering the age group evaluated. These Biochemical parameters were found to be sensitive indicators for nutritional status and can be used for diagnosis of sub clinical case of protein energy malnutrition (PEM).
\end{abstract}

\section{Introduction}

Never before in the history, has the human race faced a situation as it does today. It now stands at a point where millions in the developing countries suffer from perpetual hunger. Many die every day directly or indirectly from malnutrition. Children are the worst victims, and kwashiorkor and marasmus are the printable symbols of this immense human misery.

The World Health Organization defines undernutrition as the outcome of a variety of pathological conditions that result from deficiencies in absorption, transportation or utilization of nutrients by cells of the body. It is estimated that more than one quarter of the global population of children are currently affected by protein-energy undernutrition (PEU) [1].

Manuscript received: $10^{\text {th }}$ April 2018

Reviewed: $20^{\text {th }}$ April 2018

Author Corrected: $26^{\text {th }}$ April 2018

Accepted for Publication: $30^{\text {th }}$ April 2018
Malnutrition has been responsible, directly or indirectly, for $60 \%$ of the 10.9 million deaths annually among children under five. Under-nutrition is the underlying cause for about $50 \%$ of the 2.1 million under- 5 deaths in India each year [2]. The prevalence of under-weight children under three years and five years of age are 47 percent, 43 percent respectively. About 55 million, or one-third, of the world's under weight children under age five live in India [3]. Under nutrition in children is often accompanied by vitamin and mineral deficits. Indeed, iron deficiency anaemia (sideropenicanaemia) is the most frequent nutritional deficiency worldwide, closely followed by hypovitaminosis [4]. Protein energy malnutrition often coexists with micronutrient deficiencies reported that malnutrition results from multiple deficiencies, not necessarily limited to lack of proteins or calories, but also involving other associated or separate factors such as deficiency of trace elements, 
such as copper and zinc, lipid profile and serum sodium, serum potassium in malnutrition [5]. The first indication that severe undernutrition could cause hepatic lesions and alterations in the lipid profile was reported by Snapper et al [6] in 1965 following studies on adults who had experienced inter-uterine undernutrition during World War II. The relationship between pre-natal exposure to undernutrition and alterations in the lipid profile of adults has since been confirmed in a number of investigations carried out in developed countries [79].However, studies concerning the possible association between hepatic alterations and chronic undernutrition in childhood are scarce and dated [10-12].

Since the main function of the lipoproteins is transport of fat, it is a logic to study the profile of these in protein energy malnutrition. In India, there is paucity of work on this biochemical aspect in spite of the frequent prevalence of this disease in pediatric age group. In the present study the profile of lipoproteins will be studied and correlated with their values in patients of PEM. It was aimed to evaluate the lipid profile in infants and children with malnutrition to assess the status of lipids profile and to further evaluate the possible interrelationship between the clinical progress of the malnourished child and changes in the lipid profile in cases and controls groups. This study was a modest attempt to assess the serum lipid profile in malnutrition children of Bundelkhand region.

\section{Material and Methods}

This case control study was conducted in the Department of Pediatrics, Maharani Laxmi Bai (MLB) Medical College, Jhansi with active collaboration with Department of Medicine, Maharani Laxmi Bai Medical College, Jhansi over a period of one year from September 2009 to August 2010.

Selection of Cases- Infants and preschool children aged 6 months to 59 months suffering from malnutrition weighing less than $80 \%$ of $50^{\text {th }}$ percentile according to Indian Academy of Pediatrics (IAP) classification for their age would comprise the cases. Children were picked up from those attending ward and emergency unit of pediatric department at MLB Hospital Jhansi

Selection of Control Group- Infants and preschool children aged 6 months to 59 months weighing more than $80 \%$ of $50^{\text {th }}$ percentile according to IAP classification for their age, who will be appreciating healthy, would be selected for the control group. 108 sex matched normal children were picked from outpatient clinic at MLB Hospital served as control group.
Children suffering from primary liver disorder or disease like Diabetes Mellitus, primary hypertension, myxoedema, renal disorder and malaria etc. affecting the total lipids level would be excluded from both the control as well as study group. Hundred eight children with protein energy malnutrition were selected as cases in accordance with predefined criteria. Hundred eight healthy children served as controls. The cases and controls were comparable in relation to age, sex, weight and height. A detailed basic details, history and clinical examination were undertaken for all recruited children. Detailed anthropometry, general and systemic examinations were done and the findings were recorded in a prepared uniform proforma.

Written informed consent was taken from the parents. This study was approved by Maharani Laxmi Bai (MLB) Medical College Institutional Ethics Committee. $3 \mathrm{ml}$ of fasting venous blood samples were collected from recruited subjects at morning time.

Serum was separated and stored in aliquots at $4{ }^{\circ} \mathrm{C}$ for estimation of total lipid profile. A total lipid profile will comprise of following test.

- Total Cholesterol(TC)

- Serum Triglycerides(TG)

- High Density Lipoprotein Cholesterol(HDL)

- Low Density Lipoprotein Cholesterol(LDL)

Serum lipid profile estimation was done by enzymatic method with the help of accurex diagnostic kit as per manufacturer's instruction (manufactured by Accurex Biomedical PVT LTD, India) and the test was analyzed on Selectra-E random access analyzer (Merck). Serum LDL cholesterol (LDL) was calculated by Frederickson -Friedwald's formula according to which LDL cholesterol $=$ Total cholesterol $-($ HDL cholesterol + VLDL cholesterol). Lipid profile concentration was measured in milligram per deciliter $(\mathrm{mg} / \mathrm{dl})$. Values for lipid profiles will be considered as per Lipid Profile Norms in the Indian Children and NCEP guidelines (National Institute of Health Parent's Guide, September 1993).

- Total Cholesterol $=134.5 \mathrm{mg} \%$

- Triglycerides $=91.1 \mathrm{mg} \%$

- $\mathrm{LDL}=80.1 \mathrm{mg} \%$

- $\mathrm{HDL}=34.15 \mathrm{mg} \%$

Abnormal values will be considered as:

- Total Cholesterol > $190 \mathrm{mg} \%$

- Triglycerides $>150 \mathrm{mg} \%$

- $\mathrm{LDL}>130 \mathrm{mg} \%$

- $\mathrm{HDL}<20 \mathrm{mg} \%$ 
Analysis of data: The Statistical Package for Social Sciences (SPSS) version 19.0 software was used foranalysis of data. Appropriate statistical test were used for analysis of data. The continuous data were summarized as mean and standard deviation while discrete (categorical) in numbersand percentage (\%).
The continuous variables (Lipid profile: TC, TG, HDL, LDL) were compared by independent student's t test.

The categorical variables were comparedby chi-square $\left(\chi^{2}\right)$ test. A $P$ value of lessthan 0.05 was considered significant.

\section{Results}

In the present study 108 children with protein energy malnutrition were selected as cases in accordance with predefined criteria and 108 children served as controls. The cases and controls were comparable in relation to age, sex, weight, height \& locality.

Table-1: Baseline characteristics of children of malnourished and control groups.

\begin{tabular}{|c|c|c|c|c|}
\hline Serial No. & Characteristics & $\begin{array}{c}\text { Malnourished } \\
\mathbf{n = 1 0 8}\end{array}$ & $\begin{array}{c}\text { Control } \\
\mathbf{n = 1 0 8}\end{array}$ & p Value \\
\hline 1. & $\begin{array}{c}\text { Age in months (Mean } \pm \\
\text { SD) }\end{array}$ & $25.48 \pm 15.13$ & $25.50 \pm 15.10$ & 0.99 \\
\hline 2. & Sex (Male), n, (\%) & $63(58.3)$ & $63(58.3)$ & 1.00 \\
\hline 3. & Weight (Kg) (Mean \pm \\
SD) & $8.67 \pm 2.25$ & $85.24 \pm 12.42$ & $<\mathbf{0 . 0 0 1}$ \\
\hline 4. & Height (Cm) (Mean \pm \\
SD) & Rural, n, (\%) & $95.96 \pm 11.66$ & $93(86.11)$ & 0.69 \\
\hline 5. & (8) & & & \\
\hline
\end{tabular}

Table 1 show that clinical characteristics of two groups are summarized in Table 1. At presentation, the demographic characteristics viz. age, sex \& rural number were similar $(\mathrm{p}>0.05)$ between the two groups i.e. not differed statistically. However, clinical characteristics like weight \& height were lowered significantly $(\mathrm{p}<0.001)$ in cases as compared to controls.

Table-2: Clinical and laboratory variables among control and children with PEM.

\begin{tabular}{|c|c|c|c|c|}
\hline Serial No. & Characteristics & $\begin{array}{c}\text { Malnourished } \\
\mathbf{n = 1 0 8}\end{array}$ & $\begin{array}{c}\text { Control } \\
\mathbf{n = 1 0 8}\end{array}$ & p Value \\
\hline 1. & $\begin{array}{c}\text { Mid Upper Arm Circumference }(\mathrm{cm}), \\
\text { Mean } \pm \text { SD }\end{array}$ & $10.18 \pm 1.03$ & $13.48 \pm 2.13$ & $<\mathbf{0 . 0 0 1}$ \\
\hline 2. & Edema present,$\%$ & $40,37.08$ & 0,0 & NA \\
\hline 3. & BMI $\left(\mathrm{kg} / \mathrm{m}^{2}\right)$, Mean \pm SD & $11.82 \pm 1.67$ & $21.73 \pm 2.19$ & $<\mathbf{0 . 0 0 1}$ \\
\hline 4. & Serum Sodium mEq/L, Mean \pm SD & $137.50 \pm 7.52$ & $139.65 \pm 3.71$ & $\mathbf{0 . 0 0 5}$ \\
\hline 5. & Serum Potassium $\mathrm{mEq} / \mathrm{L}$, Mean \pm SD & $4.47 \pm 1.39$ & $4.57 \pm 0.40$ & 0.50 \\
\hline
\end{tabular}

Clinical and laboratory characteristics were summarized in table 2 where Mid Upper Arm Circumference (MUAC) \& body mass index (BMI) were significantly lower in malnourished groups. Similarly, comparing the mean sodium levels between the groups, the sodiumlevels were lowered significantly $(\mathrm{p}<0.005)$ in malnourished group but potassium level did not differ significantly in between both groups.

Table-3: Distribution of protein energy malnutritionchildrenaccording to kwashiorkor, marasmus and marasmickawashiorkor.

\begin{tabular}{|c|c|c|}
\hline PEM Groups & Number of children $(\mathbf{n}=\mathbf{1 0 8})$ & \% \\
\hline Kwashiorkor & $\mathbf{2 2}$ & $\mathbf{2 0 . 4}$ \\
\hline Marasmus & 68 & 62.9 \\
\hline Marasmic kwashiorkor & 18 & 16.7 \\
\hline
\end{tabular}

The overall children with protein energy malnutrition in present study in the form of marasmus was 68 (62.9\%), kwashiorkor was $22(20.4 \%)$ and marasmic kwashiorkor was 18 (16.7\%) as shown in table no. 3 . 
Original Research Article

Table-4: Distribution of protein energy malnutrition children according to age wise.

\begin{tabular}{|c|c|c|c|c|c|}
\hline $\begin{array}{c}\text { Serial } \\
\text { No. }\end{array}$ & Age group & $\begin{array}{c}\text { Kwashiorkor } \\
\text { N (\%) }\end{array}$ & $\begin{array}{c}\text { Marasmus } \\
\mathbf{N}(\%)\end{array}$ & $\begin{array}{c}\text { Marasmic-Kwashiorkor } \\
\text { N (\%) }\end{array}$ & p value \\
\hline 1. & $6-12$ months & $6(27.27)$ & $20(29.41)$ & $4(22.22)$ & 0.81 \\
\hline 2. & $>12-24$ months & $6(27.27)$ & $20(29.41)$ & $4(22.22)$ & 0.81 \\
\hline 3. & $>24-36$ months & $6(27.27)$ & $18(26.47)$ & $6(33.33)$ & 0.79 \\
\hline 4. & $>36-60$ months & $4(18.18)$ & $10(14.70)$ & $4(22.22)$ & 0.75 \\
\hline
\end{tabular}

Table-4 Depicts the distribution of protein energy malnutrition children according to age groups. The first group (6-12 months) included 30 malnourished children (marasmus $=20 \&$ Kwashiorkor $=6 \&$ Marasmic-kwashiorkor $=4$ ). The second group (from 12-24 months) included 30 malnourished children (marasmus $=20 \&$ Kwashiorkor $=6 \&$ Marasmickwashiorkor $=4$ ). The third group (from 24-36 months) included 30 malnourished children (marasmus $=18 \&$ Kwashiorkor $=6 \&$ Marasmic-kwashiorkor $=6$ ). The fourth group ( $>36$ Months) included 18 malnourished children $($ marasmus $=10$, Kwashiorkar $=4 \&$ Marasmic-kwashiorkor $=4)$.

Table-5: Distribution of lipid profile levels in malnourished and healthy children.

\begin{tabular}{|c|c|c|c|c|c|c|c|c|c|c|c|}
\hline $\begin{array}{l}\dot{0} \\
\frac{\pi}{\tilde{D}} \\
\dot{\mathscr{n}}\end{array}$ & 承总言总 & త્ & 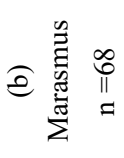 & 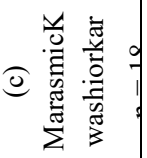 & 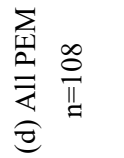 & 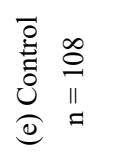 & $=\frac{0}{\stackrel{0}{7}}$ & 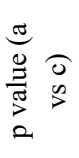 & 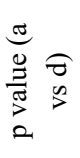 & 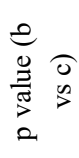 & 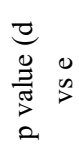 \\
\hline 1. & $\begin{array}{l}\text { Cholest } \\
\text { erol }\end{array}$ & $\begin{array}{c}171.36 \pm \\
37.23\end{array}$ & $\begin{array}{c}178.47 \pm \\
38.42\end{array}$ & $\begin{array}{c}154.50 \pm \\
20.10\end{array}$ & $\begin{array}{c}173.83 \pm \\
37.30\end{array}$ & $\begin{array}{c}180.55 \\
\pm 33.04\end{array}$ & 0.45 & 0.09 & 0.78 & 0.01 & 0.16 \\
\hline 2. & TG & $\begin{array}{c}80.23 \pm \\
31.62\end{array}$ & $\begin{array}{l}75.22 \pm \\
29.39\end{array}$ & $\begin{array}{c}67.94 \pm \\
22.70\end{array}$ & $\begin{array}{c}75.27 \pm \\
28.74\end{array}$ & $\begin{array}{r}130.68 \\
\pm 31.17\end{array}$ & 0.50 & 0.18 & 0.47 & 0.33 & $\begin{array}{c}<0.00 \\
1\end{array}$ \\
\hline 3. & HDL & $\begin{array}{c}42.82 \pm \\
2.70\end{array}$ & $\begin{array}{c}43.62 \pm \\
8.95\end{array}$ & $\begin{array}{c}45.11 \pm \\
6.72\end{array}$ & $\begin{array}{c}43.75 \pm \\
7.71\end{array}$ & $\begin{array}{c}44.53 \pm \\
5.80\end{array}$ & 0.68 & 0.15 & 0.56 & 0.51 & 0.40 \\
\hline 4. & VLDL & $\begin{array}{c}51.14 \pm \\
25.60\end{array}$ & $\begin{array}{c}51.16 \pm \\
21.44\end{array}$ & $\begin{array}{c}51.78 \pm \\
24.19\end{array}$ & $\begin{array}{c}51.31 \pm \\
22.55\end{array}$ & $\begin{array}{c}37.16 \pm \\
8.79\end{array}$ & 0.99 & 0.94 & 0.97 & 0.92 & $\begin{array}{c}<0.00 \\
1\end{array}$ \\
\hline 5. & LDL & $\begin{array}{l}81.91 \pm \\
34.39\end{array}$ & $\begin{array}{l}77.09 \pm \\
60.10\end{array}$ & $\begin{array}{c}56.83 \pm \\
12.73\end{array}$ & $\begin{array}{c}75.41 \pm \\
51.51\end{array}$ & $\begin{array}{c}70.02 \pm \\
33.74\end{array}$ & 0.72 & 0.005 & 0.57 & 0.16 & 0.36 \\
\hline
\end{tabular}

Table no 5 show distribution of lipid profile in different sub groups of protein energy malnutrition children and healthy (control) group. Serum cholesterol was significantly lowered in marasmic-kwashiorkar group as compared with marasmic children. Similarly serum triglyceride levels were significantly lowered in PEM children in comparison to healthy ones, whereas VLDL levels were significantly higher in PEM children as compared with control group. Although LDL levels were significantly lowered in marasmic-kwashiorkar group as compared with kwashiorkor groups.

\section{Discussion}

The present study assessed the lipid profile levels in malnourished children in comparison to healthy children in Budelkhand region of Uttar Pradesh. This study was a modest attempt to assess the serum lipid profile, in different type of clinical condition of malnutrition like kwashiorkor, marasmus and marasmickawashiorkor in various age groups of children.

According to $\mathrm{WHO}$, more than one quarter of the global population of children are currently affected by proteinenergy malnutrition (PEM). It constitutes a major pediatric problem in most of developing countries because it stands as a major threat to Infant's health, growth, and development. PEM covers not only the clinical spectrum, ranging from kwashiorkor to severe marasmus, but also the milder forms which manifest themselves in varying degrees of growth retardation and functional impairment in millions of poor children of the developing countries [14]. This study reflected that anthropometric parameter like weight, height, MUAC and BMI all were significantly compromised in malnourished children than the healthy children which denote that all malnourished children were suffering from acute on chronic malnutrition.

It was also noted that serum sodium levels were reduced in malnourished children, although their laboratory value was in normal range so it may not be so 
significant to cause any clinically disturbance in children but statistically it was significantly differed. In severely malnourished children excess body sodium exists even though the plasma sodium may be low. However, hyponatraemia may be seen in some children with water retention (dilutional hyponatraemia) [15]. Potassium levels were not affected in both groups, it was in normal range in both groups.It may be due to false positive reading because of hemolyzed sample. PEM children may have started oral supplementation of potassium before admission.

In present study, more than half children were suffered from marasmus as an acute malnutrition and most of children were of below 24 months of age. These results were similar to the observation made by previous study [16]. Prolonged breast feeding and delayed weaning could be the important causes of the higher mean age of marasmus group [17].

In the present study different serum lipid levels were analyzed in the malnourished groups and the control group. Different serum lipid levels such as cholesterol, triglyceride, HDL, VLDL and LDL were encountered in present study in both groups.Further, lipid profile of PEM children were measured of their three sub groups (kwashiorkor, masammus \& marasmic-kwashiorkor) Total cholesterol, triglyceride and HDL levels were lower in PEM children while LDL \& VLDL levels were higher in malnourished children group.

Serum lipids may be low normal or high and is inversely proportional to the extent of fatty liver. Defatting stage may show high values. Lipogenesis make the levels gradually normal. However low serum total lipids have been observed as probable predictors of mortality [15]. Our observations were consistent with the previous observations $[18,19,20]$.

In the present study levels of total cholesterol were significantly reduced in marasmic-kwashiorkor groups compared with other sub group of PEM children. While levels of LDL were significantly higher in Kwashiorkor sub group and overall, it was also higher in PEM children as compared with healthy children but it was not differed significantly.

The high prevalence of dyslipidemia in children in the present study demonstrated that malnutrition in early life leads to change in lipid metabolism. Kwashiorkor is the severest form of malnutrition, as lipid profile is maximally disturbed. Marasmus is the compensated form of malnutrition where lipid profile is minimally disturbed. Marasmic-kwashiorkor is a group showing a mixed pattern of changes in the lipid profile, but pattern is more close to the kwashiorkor group at the severe stage as well as during the recovery stage. While levels of triglyceride weresignificantly reduced in PEM children as compared with healthy control group, in contrast VLDL levels were significantly higher in PEM children [21].

It was assumed that the high frequency of dyslipidemia (low TG \& high VLDL) observed in the present study was a consequence of the adaptation to chronic under nutrition, although limited studies were done to support this supposition. Further, studies are to be needed especially in developing countries in larger children for future research purpose.

In present study higher levels ofVLDL and low levels of triglyceride were observedin PEM children as compared with control group, similarly observed in others studies as discussed earlier [18, 20]. However, stunting appears to have permanent effects on cholesterol metabolism, resulting in decrease in number of active hepatic receptors, which regulate cholesterol synthesis [22]. This was observed in the present study, since the serum LDL levels were high in PEM children.

Anthropometry, clinical presentation and biochemical changes form the ideal combination for assessing the severity of malnutrition. The use of these biochemical markers in pediatrics is increases because these measurements are non-invasive and generally available. These biochemical markers are capable of measuring the changes in PEM over short intervals.

There increased use has potential in better selection of patients for therapy and better monitoring of the effectiveness of therapies. The limitations for its use as indicator for nutritional status are the need for its determination and also its expensive price for those patients in the developing countries.

Funding: Nil, Conflict of interest: None initiated, Perission from IRB: Yes

\section{References}

1. Data and Statistics. WHO: Geneva, Switzerland, 2010; available online: http://www.who.int/research/en/ (accessed on 24 March 2018).

2. Mancharia CW, KOG-MAKAU W, Murok NM. Dietary intake, feeding and care practices at children in kathonzweni, Division, Makuenl, district, Kenya. East Africa Medical journal' 2004; 81: 5-6. 
3. National Family Health Survey-3 (2005-2006) International institute for population sciences, India.

4. Ferraz IS, Daneluzzi JC, Vannucchi H, Jordão AA Jr, Ricco RG, Del Ciampo LA, Martinelli CE Jr, Engelberg AA, Bonilha LR, Custódio VI. [Prevalence of iron deficiency and its association with vitamin A deficiency in preschool children]. J Pediatr (Rio J). 2005 Mar-Apr; 81 (2): 169-74.

5. Ballabriga A. The problem of malnutrition, an introduction. Ann Nestle "Malnutrition",1985; 43(1): $1-4$.

6. Snapper, I. Chinese Lessons to Western Medicine, 2nd ed.; Grune and Stratton: New York, NY, USA, 1965; pp. 55-64.

7. Roseboom, T.J.; van der Meulen, J.H.; Osmond, C.; Baker, D.J.; Ravelli, A.C.; Bleker, O.P. Plama lipid profiles in adults after prenatal exposure to the Dutch famine. Am. J. Clin. Nutr. 2000, 72, 1101-1106.

8. Lussana F, Painter RC, Ocke MC, Buller HR, Bossuyt PM, Roseboom TJ. Prenatal exposure to the Dutch famine is associated with a preference for fatty foods and a more atherogenic lipid profile. Am J Clin Nutr. 2008 Dec; 88 (6):1648-52. doi: 10.3945/ajcn. 2008. 26140

9. Lumey, L.H.; Stein, A.D.; Kahn, H.S.; Romijn, J.A. Lipid profiles in middle-aged men and women after famine exposure during gestation: the Dutch Hunger Winter Families Study. Am. J. Clin. Nutr. 2009, 89, 1737-1743.

10. Sriramachari S, Ramalingaswami V. Liver changes in kwashiorkor. Indian J Pediatr. 1953 Jan; 20 (77): $1-6$.

11. Ramalingaswami, V.; Sriramachari, S.; Patwardhan, V.N. Liver injury in protein malnutrition. Indian J. Med. $1954,8,441-443$

12. Waterlow, J.C.; De Pass, E. Further observations on the liver, pancreas, and kidney in malnourished infants and children. II. The gross composition of the liver. J. Trop. Pediatr. 1957, 2, 189-198.
13. Goodman DS. The National Cholesterol Education Program: guidelines, status, and issues. Am J Med. 1991 Feb 21;90(2A):32S-35S.

14. Waterlow JC. Kwashiorkor revisited: the pathogenesis of oedema in kwashiorkor and its significance. Trans R Soc Trop Med Hyg. 1984;78 (4): 436-41.

15. Elizabeth KE, Nutrition and Child Development, 2006, $4^{\text {th }}$ edition, Paras Medical Publisher, Hyderabad.

16. Rao P S S, Richard J: An Introduction to Biostatistics, A manual for students in health sciences, New Delhi: Prentice hall of India. 86-160.

17. Yadav YS, Yadav S, Rathi S, Dhaneria M, Poonam Singh. Comparison of Infant feeding practices among rural and urban mothers: an observational study. Int J Med Res Rev 2015; 3(6): 547-553. doi: 10.17511/ijmrr. 2015.16.104.

18. Alves JF, Britto RP, Ferreira HS, Sawaya AL, Florêncio TM. Evolution of the biochemical profile of children treated or undergoing treatment for moderate or severe stunting: consequences of metabolic programming. J Pediatr (Rio J). 2014; 90:356---62.

19. Joilane Alves Pereira, Patricia Helen Carvalho Rondo, Jesuana Oliveira Lemos, Ellaine de Oliveira, Cinthya Rocha, and Thiago Hipo' lito. Nutritional Status and Lipid Profile of Young Children in Brazil. Journal of Tropical Pediatrics, 2013; 59(1): 54-58.

20. Gabriela R. S. Veiga, Haroldo S. Ferreira, Ana L. Sawaya, Jairo Caladoand Telma M. M. T. Florêncio. Dyslipidaemia and Undernutrition in Children from Impoverished Areas of Maceió, State of Alagoas, Brazil. Int. J. Environ. Res. Public Health 2010, 7, 4139-4151; doi:10.3390/ijerph7124139.

21. Hendricks KM, Duggan C, Gallagher L, Carlin AC, Richardson DS, Collier SB, Simpson W, Lo C. Malnutrition in hospitalized pediatric patients. Current prevalence. Arch Pediatr Adolesc Med. 1995 Oct;149 (10): 1118-22.

22. Barker DJ. Mothers, babies and health in later life. 2nd ed. Edinburgh: Churchill Livingstone;1998.p.81-93

\section{How to cite this article?}

Verma G.K, Yadav Y.S, Yadav R.K, Sharma I.K, Bharat K, Yadav K.K. Study of lipid profile levels in malnourished and healthy children: a case control study. 2018;5(4):156-161. doi:10.17511/ijpr.2018.i04.01. 